\title{
Prof. Dr. Hasan Olalı Turizm Kitaplarında Yer Alan Atıfların İncelenmesi*
}

\author{
Examination of References Cited in Tourism Books by Prof. Dr. Hasan Olalı
}

\author{
Dönüş ÇiÇEK**, Ebru ZENCIR ÇiFTÇi*** \\ **Dr. Öğr. Üyesi, Anadolu Üniversitesi Yunus Emre Kampüsü Eskişehir Meslek Yüksekokulu, 26470 Tepebaşı, Eskişehir. \\ E-posta: dcicek@anadolu.edu.tr \\ ORCID: 0000-0003-3690-4442 \\ ***Dr. Öğr. Üyesi, Anadolu Üniversitesi Yunus Emre Kampüsü Turizm Fakültesi, Gastronomi ve Mutfak Sanatları Bölümü, 26470 Tepebaşı, Eskişehir. \\ E-posta: ezencir@anadolu.edu.tr \\ ORCID: 0000-0001-6668-9961
}

MAKALE BILGILERI

Makale işlem bilgileri:

Gönderilme tarihi: 14 Nisan 2019

Düzeltme: 25 Mayıs 2019

Kabul: 10 Temmuz 2019

Anahtar sözcükler: Hasan Olal, Turizm kitapları, Turizm atıfları, Bibliyometri.

\section{ARTICLE INFO}

Article history:

Submitted: 14 April 2019

Resubmitted: 25 May 2019

Accepted: 10 July 2019

Key words: Hasan Olal, Tourism books, Tourism citations,

Bibliometrics.

\section{ÖZ}

Prof. Dr. Hasan Olalı, Türkiye'de turizm, ekonomi, işletme, finansman ve pazarlama alanlarında çalışmalarıyla tanınan, alanyazının sınıflandırma düzeninin oluşmasında etkili olan ve eserleri turizm programlarında temel kitap olarak kullanılan bilim insanıdır. "Turizm Ekonomisi", "Turizm Politikası ve Planlaması", "Otel İşletmeciliği" ve "Turizm Pazarlaması" kitapları bu eserlerden bazılarıdır. Bu çalışmanın amacı, Prof. Dr. Hasan Olalı tarafından kaleme alınan turizm ile ilgili eserlerde başvurulan kaynakların bibliyometrik özellikler çerçevesinde incelenmesidir. Çalışma kapsamına alınan toplam 12 kitapta 1029 atıf bulunmaktadır. En çok atıf (139) Turizm Politikası ve Planlaması kitabında yer almaktadır. Atıf yapılan kaynakların çoğunluğunun Türkçe (403) ve Fransızca (383) eserlerden oluşmaktadır. Atıf yapılan kaynak türü arasında ilk sırada kitaplar (696) yer almaktadır. Daha çok tek yazar (741) tarafından kaleme alınan atıflarda en sık kullanılan alt konular sırasıyla; genel turizm (234), ekonomi (232), pazarlama (137) ve yönetim (76) alanındadır. Calısmanın bulguları, turizm alanyazınına önemli katkı sağlayan bilim insanı Prof. Dr. Hasan Olalı'nın eserlerinde başvurduğu kaynakların ortaya konması ve turizm alanyazınının gelişiminde hangi yazar, kurum ve ülkelerden beslendiği konusunda bilgi vermesi açısından önemlidir.

\section{ABSTRACT}

Known for his work in tourism, economics, business, finance and marketing areas, Hasan Olalı's studies were effective in the formation of the classification of tourism literature and his works are being used as essential books in tourism education. Some of these books are "Tourism Economy", "Tourism Policy and Planning", "Hotel Management", Tourism Marketing". This study aims to investigate the sources cited by Hasan Olalı in the frame of a bibliometric study. A total of 1029 citations were identified in 12 books. The majority of works cited were in the book on Tourism Policy and Planning (139), and the resources were written mostly in Turkish (403) or French (383). The citations were referred usually to books. The majority of works cited were contributed by a single author (741) and the most frequently covered sub-topics were tourism (234), economics (232), marketing (137) and management (76) respectively. The findings of the study are important in terms of revealing the sources that Hasan Olalı applied and providing evidenc about which authors, institutions and countries contributed in the development of tourism literature.

\section{GiRiş}

Türkiye turizm yazını 1920'li yıllardan 2000'lere kadar geçen dönemde, 1970’li yıllara kadar ağır, daha sonraki yıllarda ise hızlanarak gelişme gösteren bir alan olmuştur. Günümüzde, gerek tu-

* Bu çalışma, Dokuz Eylül Üniversitesi Foça Turizm Fakültesi ile Anatolia Turizm Akademisi tarafından 11-14 Ekim 2018 tarihlerinde Foça'da düzenlenen "Hasan Olalı Turizm Sempozyumu"nda sunulmuş halinin, yazarlarca daha sonra geliştirilerek düzenlenmiş halidir. rizm alanyazınını oluşturan kitap, makale, bildiri, tez, istatistik ve araştırmalar, kongre gibi akademik süreli yayınlar gerekse akademik turizm programları bakımından bu alan dünya genelinde önemli bir yere gelmiştir (Kozak 2000a: 50). Gelişmenin seyrinde birçok kurum ve kişilerin alanyazına önemli katkıları olduğu bilinmektedir. Bu kişilerden biri de 1960'lı yılların başından itibaren akademik turizm eğitiminin kurumsallaşmasına ve araştırma-yayın bağlamında tu- 
rizm alanyazınına önemli katkılar sağlayan, alanda öncülük eden Hasan Olalı'dır (Korzay 2013). 1950 yılından bu yana, gerek hazırladığ tezler, makaleler, kitaplar gerekse yetiştirmiş olduğu akademisyenler ile Olalı'nın etkisini hemen her ortamda görmek mümkündür. Bu etkinin somut kanıtı olarak yayınların incelenmesi yeterlidir. Bu çalışmanın amacı Prof. Dr. Hasan Olalı tarafından kaleme alınan turizm ile ilgili eserlerde yer alan atıfların çeşitli bibliyometrik özellikler çerçevesinde çözümlenerek bilimsel iletişime ilişkin çeşitli bulgular elde edilmesidir. Çalışmadan elde edilecek bulguların, turizm araştırmacısı ve turizm alanyazının gelişimine katkıda bulunmuş önemli bilim insanı Hasan Olalı'nın çalışmalarının, dolayısıyla da turizm alanyazınının hangi kaynaklardan beslenerek geldiği konusunda bakış açısı kazandıracağı düşünülmektedir.

\section{ALANYAZIN TARAMASI}

Türkiye turizm yazını 1920'li yıllardan 2000'lere kadar geçen dönemde, 1970'li yıllara kadar ağır ancak bu yıldan sonra hızlanarak gelişme gösteren bir alan olmuştur (Kozak 2000a: 50). Belirli bir alan hakkında bilgi sahibi olmak için, söz konusu alanda belirli dönemlerde gerçekleştirilen çalışmaların incelenmesi önemlidir (Kozak 1994). $\mathrm{Bu}$ inceleme yöntemlerinden biri de bibliyometridir. Turizm alanının disiplin olma yolundaki sürecini anlama açısından bibliyografya araştırmaları yol gösterici bir nitelik taşımaktadır (Evren ve Kozak 2014: 62).

Sayım yapmaya dayalı olan bibliyometri; basılı yayınların (dergi, kitap, bildiri vb.) bazı özelliklerinin matematiksel ve istatistiksel tekniklerle incelenerek çözümlemesine dayalı bir yöntemdir (Diodato 1994; Osareh 1996; Al ve Coştur 2007). Bilim politikalarına yön vermesi açısından önemli görülen ve ilgili alanın bilimsel iletişimi hakkında ipuçları veren bibliyometrik çalışmalarda (Al 2008) belirli bir kişi, kurum ve kuruluşların alana olan katkısı ve verimliliği (Tonta ve İlhan 2002) gibi konular incelenmektedir. Bu yöntem, akademik bir alanda yayımlanmış çalışmaları farklı parametrelere göre (konu, yıl, katkı sağlayan kurum, anahtar kelimeler, eserlerin yazar sayısı, atıflar, ortak atıflar vb.) incelemeye, bilimsel iletişime ilişkin çeşitli bazı bulgular elde etmeye dayanir.

Türkiye'de turizm alanında yapılan bibliyometrik çalışmaların yaklaşık kırk yıllık geçmişe sahip olduğu, ilk araştırmanın Ağaoğlu (1981) tarafından yapıldığı bilinmektedir. Turizm alanyazını incelendiğinde bibliyometri yönteminin birçok çalışmada kullanıldı ̆̆ ve öneminin her geçen gün arttı̆̆ı söylenebilir. Bu artışın nedeni, alandaki araştırmacı ve yapılan araştırma sayısının artması (Hall 2011), bilim adamlarının ve yayın kuruluşlarının turizm yazınına sağladıkları katkıların incelenmesine duydukları merak ya da bu kişilerin ve kuruluşların araştırma performansının değerlendirilmesi gereksinimi olduğu şeklinde açıklanabilir (Özel ve Kozak 2012: 716). $\mathrm{Bu}$ bağlamda gerçekleştirilen çalışmalar incelendiğinde, ilk yıllarda dergilerde yayımlanan makalelerin bibliyometrik yöntemle incelendiğ $i$ (Kozak 1994; İçöz ve Kozak 1999; Özel ve Kozak 2012), son zamanlarda ise alandaki lisansüstü turizm tezlerinin (Güçlü Nergiz 2014; Turan 2014; Tayfun vd. 2016) çalışma kapsamına alındığı görülmektedir. Bu tezleri, gastronomi, yiyecek-içecek, sürdürülebilir turizm şeklinde sinıflandırarak inceleyen (Güdü Demirbulat ve Tetik Dinç 2017; Sünnetçioğlu vd. 2017; Aydın 2018; Ayaz ve Türkmen 2018) çalışmalar da mevcuttur. Ayrıca kongre kitaplarında yer alan bildirilerin (Çakıcı, Yıldırım ve Karacaoğlu 2013; Yılmaz 2017; Boyraz ve Sandıkçı 2018) söz konusu yöntemle incelendiğini söylemek mümkündür. Ancak turizm kitapları üzerine bibliyometrik yöntem kullanılarak analizi gerçekleştirilen çalışma sayısı oldukça sınırlıdır. Örneğin; Altaş (2017) Türkçeye tercüme edilerek satışa sunulan gastronomi alanı ile ilgili 90 adet kitabı (1998-2017 yılları arasında); yayınlandığı yıl, yayınevi, yazar adı, çevirmen adı ve sayfa sayısı gibi bibliyometrik özellikleri açısından incelenmiştir.

\section{HASAN OLALI}

1960'lı yılların başından itibaren gerek akademik turizm eğitiminin kurumsallaşması, gerekse araştırma ve yayın bağlamında gelişimine öncülük eden Hasan Olalı, Drama'da (günümüzde Yunanistan sınırları içerisinde) doğmuştur. İlk 
ve orta eğitimini Akhisar'da, lise eğitimini İstanbul Kabataş Erkek Lisesi'nde tamamlamıştır. Yükseköğrenimini İstanbul Üniversitesi İktisat Fakültesi'nde tamamlayan (1945) Olalı, mezuniyet sonrası Milli Eğitim Bakanlığg'na bağlı Ticaret Liselerinde öğretmenlik ve müdürlük görevlerini yürütmüştür. Milli Eğitim Bakanlığı'ndan aldığı burs ile Fransa'da Jean Drouant Yüksek Turizm ve Otelcilik Okulu'nda lisansüstü çalışmasını tamamlamıştır. 1961 yılında İzmir İktisadi ve Ticari Bilimler Akademisi'nde Doktor unvanını almıştır. 1963 yılında Ege Üniversitesi İktisadi ve Ticari Bilimler Fakültesi'nde ${ }^{1}$ Doçentliğe, 1969 yılında da Profesörlüğe yükseltilmeğe hak kazanmıştır. 1970 - 1974 yılları arasında Dekanlık görevine seçilen Hasan Olalı, ayrıca İstanbul Üniversitesi İşletme İktisadi Enstitüsü'nde Öğretim Üyesi olarak görev almış ve turizm derslerinin yanı sıra finansman, kalkınma ekonomisi üzerine de dersler yürütmüştür. İzmir Ticaret Borsası'nda danışmanlık ve İzmir Ticaret Borsası Dergisi'ndeki genel koordinatörlük görevlerinde bulunmuştur (Kozak 2000a). Turizm eğitiminin gelişimi için, Eğitim Şuraları ve Milli Eğitim Bakanlığı ile Turizm Bakanlığı tarafından düzenlenen diğer şuralarda, üniversitesini genç akademisyenler ile temsil etmiştir (1975-1991). Özgün katkıları arasında, Ege Üniversitesi İktisadi İdari Bilimler Fakültesi bünyesinde Turizm Bölümü'nü ve Sosyal Bilimler Enstitüsü'nü kurmak, turizmde lisansüstü programlarını geliştirmek, İstanbul Üniversitesi İşletme Enstitüsü'nün Turizm Bölümü'nün kuruluşunda danışmanlık yapmak gelmektedir (Korzay 2013).

Türkiye'de akademik turizm alanyazınının gelişimine katkıda bulunan bilim adamları arasında Hasan Olalı'nın ayrı bir yeri olduğuna ilişkin görüş, bu alanda çalışma yapan pek çok araştırmacı ve akademisyen tarafindan kabul edilmektedir (Kozak 2000b). 1950 yılından bu yana, gerek hazırladığı tezler, makaleler, kitaplar gerekse yetiştirmiş olduğu akademisyenler ile Olalı'nın etkisini hemen her ortamda görmek mümkündür.

\footnotetext{
${ }^{1}$ Ege Üniversitesi İktisadi ve Ticari Bilimler Fakültesi 1982 yllı itibari ile yeni kurulan Dokuz Eylül Üniversitesi'ne bağlanmış ve adı İktisadi ve İdari Bilimler Fakültesi olarak değiştirilmiştir.
}

Olalı turizm ile ilgili 15'ten fazla kitap hazırlamış $^{2}$ ve bu kitaplar yaklaşık 35 yıl pek çok örgün ve yaygın eğitim programında ders materyali olarak değerlendirilmiştir. Genel itibariyle makro konulardan oluşan bu eserler arasında, Turizm Ekonomisi, Turizm Politikası ve Planlaması, Otel İşletmeciliği, Turizm Pazarlaması kitapları, turizm programlarında temel kitap olarak kullanılmıştır (Kozak 2000a).

\section{YÖNTEM}

Bilimsel iletişimin sağlanmasında aracı olan yayımların (dergi, kitap, bildiri, vb.) belirli zaman aralıkları ile incelenmesi, hem bilimsel çalışmaların o dönemdeki gelişme çizgisinin ortaya konması hem de eğilimlerin neler olduğu hakkında bilgi sahibi olunması açısından önemlidir. Bu tür çalışmalardan elde edilen bulgular, incelemeye konu olan bilim dalının zaman içerisinde gösterdiği gelişimin takibini kolaylaştırmaktadır (Kozak 1994:26). Bu amaçla kullanılan yöntemlerden biri de karar vericiler, yöneticiler, bilim uzmanları, kütüphaneciler, araştırma projesi ve bilimsel araştırma yürütenler tarafından sıklıkla başvurulan (Pendlebury 2008), bibliyometri yöntemidir. Sayım yapmaya dayalı olan bibliyometri; dergi, belge ya da diğer basılı yayınların matematiksel ve istatistiksel tekniklerle bazı özelliklerinin incelenerek ve çözümlenerek ilgili alanın bilimsel iletişimi hakkında ipuçları veren bir yöntemdir (Diodato 1994; Osareh 1996). Bu yöntem, akademik bir alanda yayımlanmış çalışmaları farklı parametrelere göre (konu, yıl, katkı sağlayan kurum, anahtar kelimeler, eserlerin yazar sayısı, atıflar, ortak atıflar vb.) incelemeye, bilimsel iletişime ilişkin çeşitli bazı bulgular elde etmeye dayanır. Bu çalışmada, Prof. Dr. Hasan Olalı tarafından kaleme alınan turizm ile ilgili kitaplarda yer alan atıfların çeşitli bibliyometrik özellikler çerçevesinde incelenmesi amaçlanmıştır.

Hasan Olalı'nın akademik hayatı boyunca yayınlamış olduğu 75 adet kitap bulunmaktadır

\footnotetext{
${ }^{2}$ Çalışmaları ile ilgili olarak bkz. Kozak, N. (2000). "Hasan Olalı: Kısa Yaşam Öyküsü ve Tespit Edilebilen Eserleri ile Yönettiği Tezlerin Bibliyografyası Üzerine Bazı Gözlemler". Anatolia: Turizm Araştırmaları Dergisi, 11 (Eylül -Aralık), s: 9-21.
} 
(Kozak 2000a). Bu yayınların 14'ü turizmi konu alan yayınlardır. Araştırma kapsamında tamamına ulaşılması hedeflenmiş, ancak "Türkiye'nin Ekonomik Gelişmesinde Turizmin Rolü (1963)" ve "Turizm, Servis İçkiler ve Ziyafet Bilgisi (1954)" kitaplarına ulaşılamamıştır. İncelenen 12 kitap (Turizm Dersleri, Dış Tanıtım ve Turizm, Turizm Pazarlaması, Turizm Politikası ve Planlaması, Ege Bölgesi Turizmi ve Turizmin Mevsimlik Karakteri, Turizm Teorisi, Otel İşletmeciliği ve Yönetimi, Otelcilik Endüstrisi Yatırımları ve Finansmanı, Turizmin Türk Ekonomisindeki Yeri, Turizm Ekonomisi, Otel İşletmeciliği, Turizm) kapsamında toplamda 1029 atıf incelenmiştir.

Bibliyometrik özelliklerin belirlenmesinde kullanılan parametreler; atıf yapılan kaynağın yılı, yazar sayısı, türü, dili, atıf yapılan kaynakların alanı şeklinde sıralanabilir. Çalışmada cevaplanacak araştırma soruları aşağıdaki gibidir:

- Atıfların kitaplara göre dağılımı nedir?

- Atıfların yıllara göre dağılımı nedir?

- Atıflar hangi dillere aittir?

- Atıfların yazar sayısı ve çok yazarlılık durumu nedir?

- En çok atıf yapılan yazar kimdir?

- Atıf yapılan kaynak türünün (kitap, makale, rapor, vb. gibi) dağılımı nasıldır?
- En çok atıf yapılan kaynak hangisidir?

- Atıfların konulara göre dağılımı nedir?

Çalışma sonucunda elde edilen bulguların, turizm araştırmacısı ve turizm alanyazının gelişimine katkıda bulunmuş önemli bilim insanı Hasan Olalı'nın çalışmalarının, dolayısıyla da turizm alanyazınının hangi kaynaklardan beslenerek geldiği konusunda turizm araştırmacılarına bakış açısı kazandıracağı düşünülmektedir.

\section{ANALIZ VE BULGULARIN YORUMLANMASI}

Türkiye'de turizm alanyazını incelendiğinde, 1945-1980 döneminde yayımlanan kitapların genel olarak turizme giriş niteliğinde olduğu, konulara makro içerikte yaklaşıldığı, bu alanla ilgili temel bilgileri içeren yayınlar olduğu söylenebilir (Kozak, 2000a). Çalışma kapsamına alınan kitaplar, basım yılları itibariyle, makro konuları kapsayan ve genel bilgileri içeren kitaplardan oluşmaktadır. Bu kitaplar ile ilgili genel bilgiler Tablo 1'de verilmiştir.

\section{Atıfların Kitaplara Göre Dağılımı}

Çalışma kapsamında incelenen 12 kitapta toplam 1029 atıf tespit edilmiştir. Bu atıfların kitaplara dağılımı incelendiğinde (Grafik 1) en çok atfın

Tablo 1. Çalışma Kapsamına Alınan Kitaplara Ait Genel Bilgiler

\begin{tabular}{lllrr}
\hline Kitap & $\begin{array}{l}\text { Basım } \\
\text { Yılı }\end{array}$ & Basım Yeri & $\begin{array}{r}\text { Sayfa } \\
\text { Sayısı }\end{array}$ & $\begin{array}{r}\text { Atıf } \\
\text { Sayısı }\end{array}$ \\
\hline Turizm Teorisi ve Politikası & 1963 & İzmir Ticaret Odası, İzmir & 304 & 44 \\
\hline Otelcilik Endüstrisi Yatırımları ve Finansmanı & 1965 & İzmir İktisadi ve Ticari İlimler Akademisi, İzmir & 202 & 107 \\
\hline Ege Bölgesi Turizmi ve Turizmin Mevsimlik Karakteri & 1968 & Ege Üniversitesi Yayınları, İzmir & 278 & 76 \\
\hline Turizm Pazarlaması & 1969 & İstiklal Matbaası, İzmir & 356 & 71 \\
\hline Turizm Dersleri & 1971 & Ticaret Matbaası, İzmir & 197 & 50 \\
\hline Otel İşletmeciliği ve Yönetimi & 1973 & Ege Üniversitesi İktisadi ve Ticari Bilimler Fak. & 717 & 112 \\
\hline Turizm Politikası ve Planlaması & 1982 & Ege Üniversitesi Matbaası & 408 & 139 \\
\hline Dış Tanıtım ve Turizm & 1983 & Türkiye İş Bankası Kültür Yayınları, Ankara & 432 & 26 \\
\hline Turizmin Türk Ekonomisindeki Yeri & 1986 & Ofis Ticaret Matbaası & 246 & 98 \\
\hline Turizm Ekonomisi & 1988 & Ofis Ticaret Matbaacılık, İzmir & 464 & 96 \\
\hline Otel İşletmeciliği & 1989 & Beta Yayınları, İstanbul & 792 & 117 \\
\hline Meslek Liseleri için Turizm & 1992 & Media Print Basım Ticaret A.Ş. İstanbul & 298 & 93 \\
\hline
\end{tabular}

Cilt 30 • Sayı 2 • Özel Sayı 2019 
Turizm Politikası ve Planlaması (139), en az atfın ise Dış Tanıtım ve Turizm (26) kitabında olduğu görülmüştür. Diğer taraftan Tablo 1 incelendiğinde kitapların sayfa sayıları ile kitaplarda yapılan atıf sayıları arasında bir ilişkinin olmadığı söylenebilir.

\section{Atıfların Yıllara Göre Dağılımı}

Çalışma kapsamında incelenen 1029 atıftan 41 atıfın yıl bilgisi bulunmamaktadır. Yıl bilgisi bulunan atıflar içerisinde en eski atıf 1931, en yeni atıf 1988 yılına aittir. En fazla atıf yapılan yıl 1964'tür (59). Kozak (2000a) turizm alanyazının gelişim evrelerini, birinci dönem (1940- 1990), ikinci dönem (1991 - 2010) ve üçüncü dönem (2011-2018) olmak üzere üç grupta ele almaktadır. Bu dönemler itibariyle çalışma sonuçları değerlendirildiğinde, en fazla atıfın birinci döneme denk geldiği söylenebilir. Aslında bu dönem turizm alanyazınının doğduğu ve geliştiği dönemdir ve bu dönemde yapılan Türkçe atıflarda; Süreyya Ergün, Selahattin Çoruh, Ziya Eralp, İhsan Çetin, Çelik Gülersoy gibi farklı disiplinlerden gelen kişilerin turizm yayınları yaptığı görülmektedir. Örneğin, söz konusu kitaplarda yapılan Türkçe atıflardan en eski tarihlisi (1944) Süreyya Ergün'e ait eser olan "Otelcilik ve Turizm Milli Kredisi" isimli kitaptır.

Çalışmada en az atıf yapılan yıllar ise 1938 ve 1949 'dur. Bu bulgu, o yıllarda turizmin çok yeni bir sektör olması, dolayısıyla da alanda gerçekleştirilen çalışma sayısının sınırlı olması ile açıklanabilir.

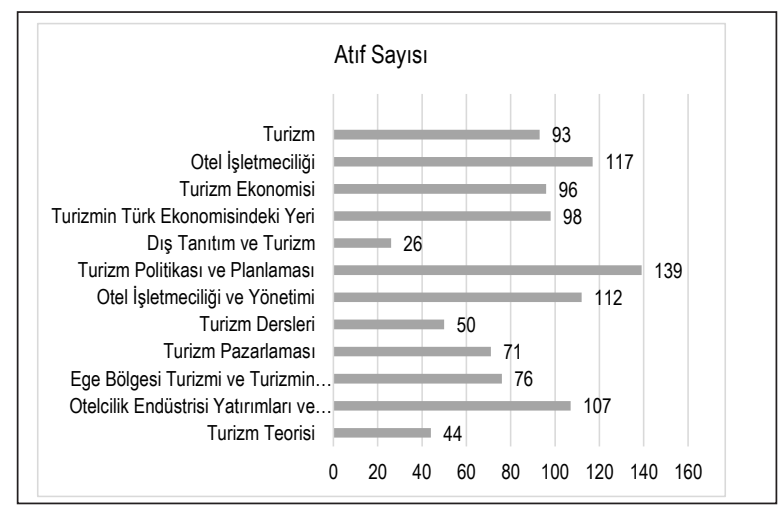

Grafik 1. Atıfların Kitaplara Dağılımı

\section{Atıfların Yazıldıkları Dillere Göre Dağılımı}

Atıflar dil parametresine göre değerlendirildiğinde; Türkçe eserlerin (403) çoğunlukta olduğu görülmüştür. Bunu Fransızca (383) ve İngilizce (228) kaynaklar takip etmektedir. Ayrıca atıflar içerisinde Almanca (14) ve Yunanca (1) kaynakların da olduğu tespit edilmiştir. Bu atıflar yıllar bazında incelendiğinde (41 atıfın yıl bilgisi bulunmadığı için yıl bazında farklılıklar bulunmaktadır) (Tablo 2), ilk yıllarda ağırlıklı olarak Fransızca kaynakların daha sonra Türkçe ve İngilizce kaynakların kullanıldığı görülmektedir.

Fransızca atıf sayısının Türkçe kaynaklardan sonra ikinci sırada yer alması, Hasan Olalı'nın Fransa'da aldığ 1 eğitim ve sonrasında da orada bulunan akademisyenlerle birlikte çalışmasıyla açıklanabilir. Bu konuda Olalı kendisiyle yapılan bir görüşmede, o dönemlerde hiç kaynağın bulunmadığını, Fransa'dan otelcilikle ilgili kitaplar getirdiğini ve orada aldığı eğitim notlarından yararlandığını ifade etmektedir (Olalı 2013). Bu durum Türkiye'de turizm alanyazının şekillenmesinde etkili olan yayınların neler olduğu konusunda fikir vermektedir. Kozak ve Kozak (2016) dünya turizm alanyazınında ilk dönem Alman ekolünün hâkim olduğunu belirtmektedir. Türkiye açısından değerlendirildiğinde ise ilk dönemlerde Fransızca sonraki yıllarda ise İngilizce eserlerin ağırlıklı kullanıldığ ${ }_{1}$ belirtilebilir. Turizm alanyazının daha çok 1960-1980 yılları arasında şekillendiği düşünüldüğünde, araştırma ve yayın birikiminin yeterli olmadığ 1 bu dönemde turizm alanında çalışan akademisyenlerin, Batı Avrupa ülkelerinde faaliyet gösteren turizm programlarındaki akademisyenlerle iletişim halinde olmaları, alanın şekillenmesinde etkili olmuştur. Türkiye'deki turizm alanyazının sınıflandırma düzeninin oluşumunda önemli rolü ortaya koyan bu sonuç Kozak'ın (2000b) çalışması ile örtüşmekte ve söz konusu çalışmada belirtildiği gibi Olalı'nın daha çok Fransız ve İngiliz araştırmacılarının eserlerini referans alması, bugünkü turizm alanyazını sınıflandırma düzeninde etkili olduğu ortaya çıkmaktadır. İngilizce eserlere yapilan atıfların 1971 - 1980 arasında artmasının nedeni ise o dönemlerin Türkiye'de turizmin yükselişe geçtiği yıllar olması ve çeşitli 
Tablo 2. Atıf Dili ve Atıf Yılı Karşılaştırması

\begin{tabular}{|c|c|c|c|c|c|c|c|}
\hline & & & Yıl & & & & \\
\hline Atıf Dili & $1931-1940$ & $1941-1950$ & $1951-1960$ & $1961-1970$ & $1971-1980$ & 1981-1988 & Toplam \\
\hline Türkçe & 6 & 16 & 29 & 162 & 99 & 78 & 390 \\
\hline Fransızca & 9 & 8 & 89 & 144 & 102 & 8 & 360 \\
\hline İngilizce & 2 & 3 & 6 & 93 & 104 & 15 & 223 \\
\hline Almanca & 0 & 3 & 9 & 2 & 0 & 0 & 14 \\
\hline Yunanca & 0 & 0 & 0 & 0 & 1 & 0 & 1 \\
\hline Toplam & 17 & 30 & 133 & 402 & 305 & 101 & 988 \\
\hline
\end{tabular}

kurum ve kuruluşların yabancı dillerde yayımlanmış nitelikli çalışmaların Türkçeye çevrilmesini sağlayarak önemli ve gerekli girişimlerde bulunmaları ile ilişkilendirilebilir. Örneğin, T1naz Titiz'in bakanlık yaptığı dönemde ILO'dan alınan birçok veri TUGEV (Turizmi Geliştirme ve Eğitim Vakfı) tarafından tercüme edilmiş ve üniversitelere dağıtılmıştır (Dallı 2013). TUGEV bu girişimiyle eğitim kalitesine büyük katkılar sağlamiştır.

Çalışmada farklı olarak göze çarpan tek dil Yunancadır. Hasan Olalı'nın aile kökenlerinin Yunanistan'a dayandığı hatırlandığında, yazarın gerekli olması halinde Yunanca yayınlara da erişiminin olduğunu/kullanabildiğini göstermektedir.

\section{Atıfların Yazar Sayısı ve Çok Yazarlılık Durumu}

Bilimsel çalışmalar incelendiğinde son yıllarda çok yazarlı yayın yapma eğiliminin yaygınlaşmakta olduğu gözlenmektedir. Özellikle son çeyrek asırda yayın başına düşen yazar sayısında ciddi bir artışın olduğu görülmektedir. Al (2005: 41) bu durumun nedenlerini, araştırmaların giderek daha büyük ölçekli hale gelmesinin yanı sıra ürünün ortaya çıkabilmesi için çok kişiye gereksinim duyulması ile açıklamaktadır. Yazar bunların yanı sıra iletişim olanaklarının artmas1, araştırmacıların birlikte hareket ederek daha çok sayıda yayın yapma olanağı bulması gibi nedenlerin de çok yazarlı çalışma sayılarını artıran etkenlerden olduğunu belirtmektedir. Bilindiği gibi çok yazarlılık, bireylerin farklı bakış açıları ile düşünmesini sağlayabileceği gibi, tek kişinin gözünden kaçabilecek olası hataları en aza in- dirmede de yardımcı olmaktadır. Ancak Hasan Olalı'nın yayınlarında günümüzde gerçekleştirilen diğer çalışmalara (Al 2005; Çiçek ve Kozak 2012) göre tek yazarlı çalışmaların önemli derecede ağırlıkta olduğu $(\% 74,1)$, çok yazarlı çalışmaların son derece az olduğu $(\% 9,9)$ tespit edilmiştir. Bu farklılık söz konusu eserlerin yayım yılları ile açıklanabilir. Çünkü o dönemler iletişim teknolojilerinin henüz çok gelişmediği yıllardır. Diğer taraftan atıfların yıllar bazında yazar sayısıyla karşılaştırılması (Tablo 3) durumunda 1971 itibariyle iki ve üç yazarlı yayınların sayısında az da olsa bir artış olduğu tespit edilmiştir.

Yazarlar açısından bir değerlendirme yapıldığında, en çok atıfın (72) Olalı'nın eserlerine yapıldığ 1 tespit edilen sonuçlardandır. Özatıf kapsamında değerlendirebilecek bu sonuç, o dönemde turizm alanyazınında Türkçe eser sayısının fazla olmaması ile açıklanabilir. Bunu sırasıyla; Archer (21), Hunziker (21), Defert (19), Gülersoy (18), Beratje (14), Gautier (12), Krapf (12), Akoğlu (11) ve Haulot (11) takip etmektedir. Bu yazarların çoğunluğunun iktisatçı olması o dönemlerde dünyada turizmin ülke ve yöre ekonomilerine yaptığı olumlu katkılar yönüyle ele alınması ve bu yönde çalışmaların yapılması ile açıklanabilir (Kozak ve Kozak 2016).

Çalışmada dikkati çeken bir diğer konu gerek yerli kurumların gerekse yabancı kurumların yayınlamış olduğu rapor, bülten gibi basılı yayınlara yapilan atıflardır $(\% 15,7)$. Bunlardan en fazla (38) atıf alan kurum Resmi Turizm Teşekkülleri Milletlerarası Birliği'dir (Union Internatıonale des Organismes Officiels de Tourisme /UIOOT). Daha 
Tablo 3. Atıf Yılı Periyodu/ Çok Yazarlılık Karşılaştırması

\begin{tabular}{|c|c|c|c|c|c|c|c|}
\hline YII & $1931-1940$ & $1941-1950$ & $1951-1960$ & $1961-1970$ & $1971-1980$ & 1981-1988 & Toplam \\
\hline \multicolumn{8}{|c|}{ Yazar Sayısı } \\
\hline 1 & 14 & 27 & 116 & 313 & 201 & 70 & 741 \\
\hline 2 & 2 & 3 & 12 & 23 & 31 & 10 & 81 \\
\hline 3 & 0 & 0 & 0 & 0 & 16 & 2 & 18 \\
\hline 4 & 0 & 0 & 0 & 1 & 1 & 0 & 2 \\
\hline 5 & 0 & 0 & 0 & 1 & 2 & 0 & 3 \\
\hline Kurum & 1 & 0 & 5 & 64 & 54 & 19 & 143 \\
\hline Toplam & 17 & 30 & 133 & 402 & 305 & 101 & 988 \\
\hline
\end{tabular}

sonra Devlet Planlama Teşkilatı (14) ve American Hotel and Motel Association (13) gelmektedir. Bu aşamada yazar veya kurumların tek bir atıfı üzerinden değil, bütün yayınları dikkate alınarak sıralama gerçekleştirilmiştir.

\section{Atıf Yapılan Kaynak Türünün Dağılımı}

Atıf yapılan kaynaklar; kitaplar, makaleler, kurum ve kuruluşlara ait raporlar, ders notları, teksir, bildiriler, tezler ve haber, reklam, bülten vb. yer aldığı diğer kaynaklar şeklinde sinıfland1rılmıştır. Atıfların 696 tanesini kitaplar oluşturmaktadır. Bunu makale (118), rapor (81), teksir (30), diğer (29), kitap çevirisi (24), bildiri (24) ve tez (14) takip etmektedir. En az atıf ise belli bir dönemde daha sık kullanılan, günümüzde ise neredeyse kaynak olarak hiç kullanılmayan ders notlarına (13) yapılmıştır. İncelenen kitapların yılları dikkate alındığında en çok kullanılan kaynak türünün kitap olması olağandır. Turizm alanındaki dergilerin sayısı her geçen gün artmakla birlikte, 1980'li yıllara kadar dergi sayısının, dolayısıyla makale sayısının fazla olmaması, kongre sayılarının sınırlı olması makale ve bildirilere yapılan atıf sayısının az olmasinın nedeni olarak gösterilebilir. Bu bağlamda en çok atıf yapılan kaynak değerlendirilmiş, yapılan sıralamada en çok atıfın Olalı ve Timur tarafından kaleme alınan Turizm Pazarlaması (7) kitabına yapıldığ1 görülmüştür. Bunu Çelik Gülersoy'un Sosyal Turizm (6), Hunziker'in Betriebwirtschaftslehre des Fremdenverkehrs (5), Baretje'nin la Deman- de Touristique (5) takip etmektedir. Dergi bazında ise Revue de Tourisme (23) en çok atıf yapılan dergidir. Araştırmada dikkati çeken bir diğer konu diğer olarak gruplandırılan haber, reklam, bülten ve benzeri kaynakların da azımsanmayacak kadar (29) kullanılması olmuştur. Bu durum da yine geçmiş yıllarda kaynak sayısının az olması ve günümüzde fazla tercih edilmeyen çeşitli kaynaklara başvurulması ile açıklanabilir.

\section{Atıfların Konulara Göre Dağılımı}

Atıfların hangi konular kapsamında olduğu çalışmada incelenen konular arasındadır. Alt konulara karar verilebilmesi için öncelikle atıflar başlıkları itibariyle sıralanmış, üç uzman akademisyen tarafından değerlendirmeler gerçekleştirilmiş ve böylece 26 alt konu belirlenmiştir. Bunlar; araştırma yöntemleri, bölge planlama, coğrafya, çevre bilimleri, eğitim, ekonomi, finans, genel turizm, halkbilim, hukuk, iktisadi planlama, iktisat politikası, iletişim, istatistik, işletme, kamu yönetimi, mimarlık, muhasebe, pazarlama, rekreasyon, sağlık, sosyoloji, tarih, ulaştırma, yönetim ve diğer başlıklarında gruplandırılmıştır. Atıflarda en sık kullanılan alt konuların sirasiyla; genel turizm (234), ekonomi (232), pazarlama (137) ve yönetim (76) olduğu tespit edilmiştir. Görüldügü gibi kaynaklar çok farklı disiplinlere ait alt konuları içermektedir ve bu da turizmin disiplinlerarası bir çalışma alanı olmasıyla açıklanabilir. En fazla ilişkili olduğu konular ise beklendiği gibi ekonomi, pazarlama ve yönetimdir. Günü- 
müzde de turizm araştırmalarının önemli bir kısmının aynı disiplinler çerçevesinde yoğunlaştığı söylenebilir.

Atıflarda yer alan alt konular yıllar bazında değerlendirildiğinde (Tablo 4), dikkati çeken ilk nokta 1961-1970 aralığında genel turizm alt başlığında yapılan atıflardır. Bunu ekonomi, pazarlama ve yönetim konuları takip etmektedir. $\mathrm{Bu}$ durum değerlendirildiğinde, 1961 sonrasındaki on yıllık dönemdeki yayın artışının sadece turizm alanına olan ilginin artması değil, aynı zamanda akademik yayınların sayısında olan artış ile de ilişkilendirilebilir. Tablonun kaynaklar üzerinden oluşturulduğu dikkate alındığında değerlendirilebilecek bir diğer konu incelenen en yeni yayının 1988 yılına ait olmasıdır. Bu durumda 1971-1980 ve özellikle 1981-1988 periyodlarında atıf sayısının azalması olağan kabul edilebilir. Her ne kadar bu çalışmada hesaplanmasa da aslında bu veri, alanyazının dönem itibariyle hızlı yaşlanmadığına da işaret ediyor olabilir. Hem 1970'li hem de 1980'li y1llardaki kaynaklarda alandaki daha eski kaynaklar olan 1961-1970 aralığındaki kaynaklara atıf yapıldığı görülmektedir. Bu da kavramların temellerini oluşturan temel eserlerin bu yıllar arasında kaleme alındığ şeklinde yorumlanabilir. Tabloda dikkati çeken bir diğer alt konu iktisadi planlama konusunun işlenme sıklığı olmuştur.

\section{SONUÇ}

Turizm alanı pek çok bilim dalına göre genç bir bilim olarak değerlendirilebilir. Gerek dünyada gerekse Türkiye'de gelişimi yakın bir geçmişe dayanan bu alan, 1950'li yıllarla birlikte büyük bir ivme kazanmıştır. Turizmin temel çalışma konuları, diğer anabilim dalları üzerine şekillenmiş, farklı disiplinlerdeki akademisyenlerin ilgi göstermesiyle yükselişe geçmiştir. Farklı disiplinde yetişip daha sonra turizme önemli katkılar sağlayan isimlerden biri Prof. Dr. Hasan Olalı'dır. Lisans eğitimini iktisat alanında yapan Olalı, Fransa'da almış olduğu turizm eğitimi sayesinde Türkiye'de turizm alanyazınına önemli katkılar sağlamıştır. Bu katkının ortaya konması amacıyla, bu çalışmada Hasan Olalı tarafından kaleme alınan turizm ile ilgili kitaplarda yer alan atıflar çeşitli bibliyometrik özellikler çerçevesinde incelenmiştir.

Araştırma kapsamında Olalı tarafından kaleme alınan 14 eserden ulaşılabilen 12'si analiz edilmiştir. Toplamda 1029 atıf incelenmiş, en çok atıfın Turizm Politikası ve Planlaması adlı kitapta kullanıldığı görülmüştür. Olalı'nın almış olduğu Fransızca eğitimin etkisiyle yayınlarında kullanılan kaynakların dilinin ağırlıklı olarak Türkçe ve Fransizca olduğu tespit edilmiş, 1970'i yıllarla birlikte bu eğilimin İngilizceye doğru yöneldiği gözlemlenmiştir. Bu sonuç, alanyazında dün-

Tablo 4. Atıf Yılı Periyodu/ Alt Konu Karşılaştırması

\begin{tabular}{|c|c|c|c|c|c|c|c|}
\hline \multirow[b]{2}{*}{ Alt Konu } & \multirow[b]{2}{*}{ 1931-1940 } & \multicolumn{6}{|c|}{$Y_{l l}$} \\
\hline & & 1941-1950 & $1951-1960$ & 1961-1970 & 1971-1980 & 1981-1988 & Toplam \\
\hline Genel Turizm & 9 & 9 & 23 & 94 & 68 & 25 & 228 \\
\hline Ekonomi & 2 & 8 & 23 & 88 & 73 & 27 & 221 \\
\hline Pazarlama & 0 & 0 & 20 & 56 & 44 & 15 & 135 \\
\hline Yönetim & 0 & 3 & 8 & 34 & 25 & 4 & 74 \\
\hline Muhasebe & 2 & 0 & 11 & 14 & 10 & 1 & 38 \\
\hline İktisadi Planlama & 0 & 0 & 2 & 12 & 10 & 10 & 34 \\
\hline Finans & 0 & 1 & 7 & 19 & 3 & 3 & 33 \\
\hline Eğitim & 0 & 0 & 8 & 10 & 9 & 5 & 32 \\
\hline Diğer & 4 & 9 & 31 & 75 & 63 & 11 & 193 \\
\hline Toplam & 17 & 30 & 133 & 402 & 305 & 101 & 988 \\
\hline
\end{tabular}


yada Alman ekolünün hâkim olduğu dönemde, Türkiye'de daha çok Fransız ve İngiliz kaynaklarının kullanıldığı bilgisine ulaşılmasını sağlamıştır. Yıllar içerisinde çok yazarlılık durumunun arttığ Hunziker, Defert gibi turizm tanımına önemli katkılar sağlayan isimler öne çıkmış, Türk araştırmacilardan da Türk turizmine katkılarıyla bilinen Çelik Gülersoy'un en fazla atıf alan yazar olduğu tespit edilmiştir.

Turizmin araştırıldığı ilk yıllardaki katkılarıyla dünyada turizm alanına katkı sağlayan bu isimlerin kitapları günümüzde de referans kitaplar olarak kullanılmakta olup kaynak gösterildikleri yılların müstesna eserleridir. Farklı disiplinlerden beslenen turizmde, ilk yıllar ekonomi, pazarlama ve yönetim gibi konular ağırlıkta olurken, 1960'lı yıllarla birlikte genel turizm araştırmalarının hız kazandığı görülmüştür. Bu dönem turizmin ayrı bir bilim dalı olarak incelenmesiyle açıklanabilir. Bütün bu açıklamalar Prof. Dr. Hasan Olalı'nın eserlerinde geniş dil bilgisi sayesinde farklı disiplinlerden temel eserleri inceleyip turizm kitaplarında bu temel kaynaklara yer verdiğini göstermiştir. Günümüz turizm kitaplarında hala kaynak olarak kullanılan bu kitapların 1950'li 60'lı yıllarda Türkçe kitaplarda yer alması turizm alanının anlaşılmasında ve gelişmesinde önemli katkı sağlamıştır. Günümüze nazaran kıt olan kaynakların bu şekilde değerlendirilmesi dönem itibariyle önemli bir öngörü olarak değerlendirilebilir. Prof. Dr. Hasan Olalı'nın günümüz turizm camiası tarafından hala saygiyla anılması da bu öngörü ve emeğin bir sonucudur.

\section{KAYNAKÇA}

Ağaoğlu, B. (1981). İzmir İktisadi ve Ticari İlimler Akademisi'nde Yapilan Turizm Tezleri, http://anatoliajournal.com/atad/depo/bilgibankasi/bulent_036.pdf, Erişim tarihi: 13 Mayss 2019.

Al, U. (2005). Çok Yazarlılı̆̆ın Bilimsel İletişimdeki Yeri. İçinde M. E. Küçük (Editör), Prof. Dr. Nilüfer Tuncer'e Armağan (ss. 31-41). Ankara: Türk Kütüphaneciler Derneği.

Al, U. (2008). Türkiye'nin Bilimsel Yayın Politikası: Atıf Dizinlerine Dayalı Bibliyometrik Bir Yaklaşım. (Basılmamış Doktora Tezi). Ankara: Hacettepe Üniversitesi Sosyal Bilimler Enstitüsü Bilgi ve Belge Yönetimi Ana Bilim Dalı.

Al, U. ve Coştur, R. (2007). Türk Psikoloji Dergisi'nin Bibliyometrik Profili, Türk Kütüphaneciliği, 21 (2): 142-163.
Altaş, A. (2017). Türkçeye Tercüme Edilen Gastronomi Kitaplarının Bibliyometrik Analizi, Kırklareli Üniversitesi Sosyal Bilimler Dergisi, 1 (1): 103-117.

Ayaz, N. ve Türkmen, B. M. (2018). Yöresel Yiyecekleri Konu Alan Lisansüstü Tezlerin Bibliyometrik Analizi, Gastroia: Journal of Gastronomy and Travel Research, 2 (1): 22-38.

Aydın, B. (2018). YÖK Tez Merkezinde Yiyecek İçecek İşletmeciliği Alanında Kayıtlı Bulunan Tezlerin Bibliyometrik Analizi, Disiplinlerarası Akademik Turizm Dergisi, 2 (1): 23-38.

Boyraz, M. ve Sandıkçı, M. (2018). Gastronomi Bildirilerinin Değerlendirilmesi: Turizm Kongreleri Örneği (20132017), Journal of Tourism and Gastronomy Studies, 6 (4): 873- 889.

Çakıcı, A. C., Yıldırım, O. ve Karacaoğlu, S. (2013). Ulusal Turizm Kongreleri Bildirilerinin Bibliyometrik Profili, 14. Ulusal Turizm Kongresi (ss. 1429-1447). Kayseri.

Çiçek, D. ve Kozak, N. (2012). Anatolia: Turizm Araştırmaları Dergisi'nde Yayımlanan Hakem Denetimli Makalelerin Bibliyometrik Profili, Türk Kütüphaneciliği, 26 (4):734756.

Dallı, Ö. (2013). Türkiye Turizmi Tarihi kapsamında gerçekleştirilen görüşme. (23 Kasım 2013), İstanbul. (Görüşen: Dönüş Çiçek).

Diodato, V. P. (1994). Dictionary of Bibliometrics. ABD: The Hawthorne Press.

Evren, S. ve Kozak, N. (2013). Bibliometric Analysis of Tourism and Hospitality Related Articles Published in Turkey, Anatolia-An International Journal of Tourism and Hospitality Research, 25 (1): 61-80.

Güçlü Nergiz, H. (2014). Türkiye'de Lisansüstü Turizm Tezlerinin Bibliyometrik Profili (1990-2013), VII. Lisansüstü Turizm Öğrencileri Araştırma Kongresi Bildiriler Kitabı (ss. 212-221). Aydın: Anatolia Turizm Araştırmaları Dergisi ve Dokuz Eylül Üniversitesi.

Güdü Demirbulat, Ö. ve Tetik Dinç, N. (2017). Sürdürülebilir Turizm Konulu Lisansüstü Tezlerin Bibliyometrik Profili, Seyahat ve Otel İşlemeciliği Dergisi, 14 (2): 20-30.

Hall, C. M. (2011). Publish or Perish? Bibliometric Analysis, Journal Ranking and The Assesment of Research Quality in Tourism, Tourism Management, 32(1): 16-27.

İçöz, O. ve Kozak, N. (1999). Turizm İşletmeciliği Dergisi'nin Turizm Literatürüne Katkısı Hakkında Bir İnceleme, Anatolia: Turizm Araştırmaları Dergisi, 10 (Eylül-Aralık): 9-17.

Korzay, M. (2013). Hasan Olalı: Eğiticilerin Eğitmeni, Anatolia: Turizm Araştırmaları Dergisi, 24 (2): 276 - 280.

Kozak, N. (1994). Anatolia: Turizm Araştırmaları Dergisi'nde Yayımlanan Yazılar Üzerine Bir İnceleme, Anatolia: Turizm Araştırmaları Dergisi, 5 (Aralık): 22-33.

Kozak, N. (2000a). Türkiye'de Akademik Turizm Literatürünün Gelişim Süreci Üzerine Bir İnceleme, DAÜ: Turizm Araştırmaları Dergisi, 1 (1):15-55.

Kozak, N. (2000b). Hasan Olalı: Kısa Yaşam Öyküsü ve Tespit Edilebilen Eserleri ile Yönettiği Tezlerin Bibliyografyası Üzerine Bazı Gözlemler, Anatolia: Turizm Araştırmala$r$ Dergisi, 11 (Eylül -Aralık): 9-21. 
Kozak, M. ve Kozak, N. (2016). Institutionalisation of Tourism Research and Education: From The Early 1900s to 2000s, Journal of Tourism History, 8 (3): 275-299. https:// doi.org/10.1080/1755182X.2017.1284274, Erişim tarihi: 24 Mart 2018.

Olalı, H. (2013). Türkiye Turizmi Tarihi kapsamında gerçekleştirilen görüşme. (25 Eylül 2013), İzmir. (Görüşen: Ece Tandoğan).

Osareh, F. (1996). Bibliometrics, Citation Analysis and Co- Citation Analysis: A Review of Literature, Libri, 46: 149158.

Özel, Ç. H. ve Kozak, N. (2012). Turizm Pazarlaması Alanının Bibliyometrik Profili (2000-2010) ve Bir Atıf Analizi Çalışması, Türk Kütüphaneciliği, 26 (4): 715- 733.

Pendlebury, D. A. (2008). White Paper Using Bibliometrics in Evaluating Research. Web of Knowledge. http://wokinfo. com/media/pdf/UsingBibliometricsinEval_WP.pdf, Erişim tarihi: 2 Nisan 2018.

Sünnetçioğlu, S., Yalçınkaya, P., Olcay, M. ve Mercan, Ş. O. (2017). Turizm Alanında Yazılmış Olan Gastronomiye
İlişkin Tezlerin Bibliyometrik Profili, Journal of Tourism and Gastronomy Studies, 5 (Special issue2): 345-354.

Tayfun, A., Küçükergin, F. N., Aysen, E., Eren, A. ve Özekici, Y. K. (2016). Turizm Alanında Yazılan Lisansüstü Tezlere Yönelik Bibliyometrik Bir Analiz, Gazi Üniversitesi Turizm Fakültesi Dergisi, 1 (1): 50-69.

Tonta, Y. ve İlhan, M. (2002). Contribution of Hacettepe University Faculty of Medicine to the World's Biomedical Literature (1988-1997), Scientometrics, 55 (1): 123-136.

Turan, A. (2014). Turizm Konulu Yüksek Lisans Tezlerinin Bibliyometrik Özellikleri (1984-2013), VII. Lisansüstü Turizm Öğrencileri Araştırma Kongresi Bildiriler Kitabı (ss. 3-15), Aydın: Anatolia Turizm Araştırmaları Dergisi ve Dokuz Eylül Üniversitesi.

Yılmaz, G. (2017). Ulusal Turizm Kongrelerinde Gastronomi ve Mutfak Sanatları Alanı ile İlgili Yayınlanan Bildiriler Üzerine Bir Araştırma, Turizm ve Araştırma Dergisi, 6 (1): 1-21.

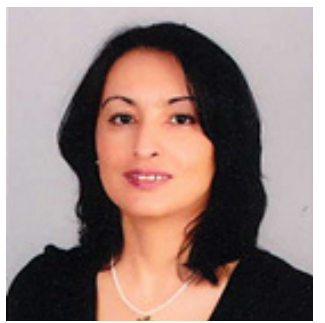

\section{Dönüş ÇiçEK}

Anadolu Üniversitesi Turizm ve Otel İ̧̧letmeciliği Yüksekokulu'ndan mezun oldu (1997). Yüksek lisans derecesini Anadolu Üniversitesi Turizm ve Otel İ̧̧letmeciliği Dalı’ndan (2000), doktora derecesini de Eskişehir Osmangazi Üniversitesi Turizm İşletmeciliği Dalı'ndan aldı (2017). Balıkesir Üniversitesi'nde çalıştı (1998 - 2004). 2004 yılında Anadolu Üniversitesi'nde çalışmaya başladı. Halen Anadolu Üniversitesi Eskişehir Meslek Yüksekokulu'nda görev yapmaktadır. Temel çalışma alanları, kat hizmetleri, alternatif turizm, turizm ve kalkınmadır.

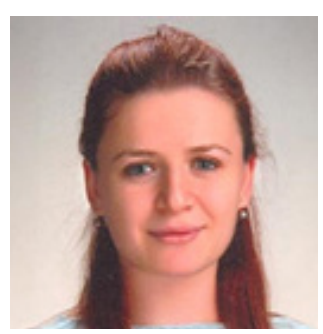

\section{Ebru ZENCiR ÇiFTÇi}

Anadolu Üniversitesi Turizm ve Otel İşletmeciliği Yüksekokulu'ndan mezun oldu (1997). Yüksek lisans derecesini Anadolu Üniversitesi'nden Turizm ve Otel İşletmeciliği Dalı'ndan (2004), doktora derecesini de Anadolu Üniversitesi'nden Turizm ve Otel İşletmeciliği Dalı'ndan aldı (2013). Anadolu Üniversitesi'nde çalışmaya başladı (2006). Çeşitli otel ve seyahat acentelerinde çalıştı (1995-2006). Halen Anadolu Üniversitesi Turizm Fakültesi'nde görev yapmaktadır. Temel çalışma alanları, restoran yöneti$\mathrm{mi}$, gastronomi ve turizm işletmeciliğidir. 